\title{
KINERJA PROGRAM STUDI ADMINISTRASI PENDIDIKAN \\ FAKULTAS ILMU PENDIDIKAN \\ UNIVERSITAS NEGERI JAKARTA \\ (JAKARTA, 2017)
}

\author{
Shefanny Nur Layla, Prof. Dr. Rugaiyah, M.Pd, Dr. Desi Rahmawati, M.Pd \\ Administrasi Pendidikan FIP UNJ \\ shefanny150994@gmail.com
}

\begin{abstract}
The improving of performance in educational institution is expected to produce a good output. Many things must be prepared and have good performance to achieve the quality institution. This study focuses on the evaluation of the implementation of the Standards and Procedures Accreditation of Undergraduate Studies at Higher Education level in Education Administration Studies Program Faculty of Education, Universita Negeri Jakarta. The scope of study is limited to the evaluation of the implementation of standards and procedures for accreditation.

This study uses Discrepancy Evaluation Model (DEM) as model evaluation. It evaluates the gaps of program that is based on intermediate state which is expected in the plan with that generated in the implementation of the program. Evaluation of the gap is intended to determine the level of compatibility between the standards prescribed in the program with the actual appearance of the program. The data source is data of financing,insfrastructure, information system, research, community service and cooperation in year 2013-2015.s

These results indicate that; (1) the performance component on financing aspects, the aspect of financing is not directly managed by the study program. (2) the existing components of the infrastructure shows the percentage of achievement in the category of good. (3) the component information system shows the percentage of achievement in the category of good. (4) component research, community service and cooperation shows the percentage in the category of pretty good achievement. Based on the acquisition of the four components of the above, the performance Educational Administration Faculty of Education UNJ aspects of financing, infrastructure, information systems, research, service and cooperation demonstrated has good category.
\end{abstract}

Keywords: Performance, Funding, Facilities and Infrastructure, Information Systems, Research, Community Service and Cooperation

\section{Pendahuluan}

Pembangunan pendidikan pada dasarnya sama pentingnya dengan pembangunan bangsa. Pembangunan bangsa akan sulit digerakan jika sumber daya manusianya (SDM) tidak mempunyai kemampuan dan ketrampilan. Sebagai contoh Singapura atau Jepang, yang dimana negara tersebut tidak memiliki sumber daya alam yang cukup besar, akan tetapi negara tersebut dapat maju dengan pesat di segala bidang. Hal ini dapat terjadi karena sumber daya manusia di Negara tersebut lebih berkualitas dan berpendidikan. Itulah yang menjadikan pendidikan sangat penting dan harus menjadi prioritas utama dalam suatu negara. Pendidikan berkualitas akan merubah suatu negara menjadi lebih maju. 
Menurut Undang-Undang Sisdiknas Pasal 19 Ayat 1, Pendidikan tinggi merupakan jenjang pendidikan setelah pendidikan menengah yang mencakup program pendidikan diploma, sarjana, magister, spesialis dan doktor yang diselenggarakan oleh pendidikan tinggi.

Pendidikan yang berkualitas tidak lepas dari pengoptimalan sumberdaya yang ada. Penyelenggaran pendidikan tidak lepas dari pembiayaan. Di sebuah lembaga pendidikan pasti memerlukan perencanaan, pengelolaan dan pelaporan dana yang dipakai demi kelancaraan kegiatan lembaga pendidikan tersebut.

Penyelenggaraan kegiatan belajar mengajar tidak pernah lepas dari sarana dan prasarana. Sarana dan prasarana merupakan penunjang keberhasilan pembelajaran di lembaga pendidikan. Saran dan prasarana yang memadahi dapat menunjang keberlangsungan pembelajaran dengan baik.

Pada zaman teknologi seperti ini, banyak cara yang mampu memudahkan seseorang untuk mencari sebuah informasi. Guna mempermudah pembelajaran dan memberikan informasi kepada masyarakat mengenai lembaga pendidikan tersebut. Sistem Informasi yang baik mampu memberikan manfaat bagi semua pihak dari civitas akademika dan masyarakat luas.

Tri dharma pendidikan perguruan tinggi salah satunya adalah berkaitan dengan penelitian. Perguruan tinggi tidak pernah lepas dari penelitian. Dilaksanakannya penelitian merupakan salah satu cara untuk mengembangkan dan menemukan ilmu-ilmu yang dapat dipakai untuk kehidupan masyarakat luas. Perguruan tinggi tidak dapat berdiri sendiri, pastilah ada kerjasama yang dilaksanakan demi keberlangsungan kegiatan di lembaga pendidikan tersebut.

Melalui peningkatan kinerja sebuah lembaga pendidikan diharapkan mampu menghasilkan output yang baik. Banyak hal yang harus dipersiapkan dan kinerja yang baik untuk mewujudkan lembaga yang berkualitas.

Program studi merupakan penataan program akademik bagi bidang studi tertentu yang didedikasikan untuk: (1) menguasai, memanfaatkan, mendiseminasikan, mentransformasikan dan mengembangkan ilmu pengetahuan, teknologi, dan seni (IPTEKS) dalam bidang studi tertentu, (2) mempelajari, mengklarifikasikan dan melestarikan budaya yang berkaitan dengan bidang studi tertentu, serta (3) meningkatkan mutu kehidupan masyarakat dalam kaitannya dengan bidang studi tertentu. Oleh karena itu program studi sebagai lembaga melaksanakan fungsi Tridarma Perguruan Tinggi, yaitu pendidikan, penelitian dan pengabdian kepada masyarakat, serta mengelola Ipteks selaras dengan bidang studi yang dikelolanya. Untuk menopang dedikasi dan fungsi tersebut, program studi harus mampu mengatur diri sendiri dalam upaya meningkatkan dan menjamin mutu secara berkelanjutan, baik yang berkenaan dengan masukan, proses maupun keluaran program akademik dan layanan yang diberikan kepada masyarakat selaras dengan bidang studi yang dikelolanya.

Administrasi pendidikan merupakan organisasi yang ada di tingkat terkecil di struktur birokrasi lembaga pendidikan Universitas Negeri Jakarta. Administasi pendidikan merupakan prodi yang mempunyai visi dan misi untuk menghasilkan sumber daya manusia yang mampu bersaing di dunia pendidikan guna menciptakan pendidikan yang berkualitas di tingkat mikro, meso dan makro. Prodi ini berlokasi di gedung daksinapati lantai 1 kampus A UNJ. Dr. Supadi, M.Pd merupakan koordinator prodi Administrasi Pendidikan. Administrasi Pendidikan memiliki akreditasi A pada tahun 2013. Akreditasi yang telah 
didapat ini diharapkan mampu memberikan semangat untuk melakukan yang terbaik. Mempertahankan akreditasi A tidaklah mudah dengan begitu dibutuhkannya persiapan yang baik sehingga mempu menghasilkan yang terbaik.

Peningkatan kualitas melalui kinerja yang dilakukan oleh program studi dimaksudkan untuk menghasilkan lulusan yang berkualitas, terampilan dan yang berguna untuk dirinya sendiri, lingkungan dan bangsa. Baiknya kualitas kinerja yang dimiliki program studi mampu mempertahankan akreditasi yang baik sehingga persiapan dan peningkatan kualitas harus terus dipantau serta dipersiapkan dengan baik.

\section{Tinjauan Pustaka}

$$
\text { Straka dalam }
$$

bukunya berjudul Measurement and Evaluation of Competence menyatakan bahwa "Evaluation judges measured competences against a defined benchmark." Hal ini mengungkapkan bahwa penentuan evaluasi diukur berdasarkan kompetensi terhadap patokan yang sudah ditetapkan. Kriteria evaluasi merujuk pada penafsiran dan penilaian kompetensi yang diukur dalam batasan yang jelas sebagaimana yang dikemukakan Straka, "Criterionreferenced evaluation is interpreting and judging the measured competence in terms of a clearly defined and delimited domain." Selanjutnya dijelaskan pula tipe evaluasi sebagai berikut: "Other terms for this type of evaluation are: standards-based, objective referenced, content referenced, domain referenced, and universe referenced."

Menurut David Royse dkk. " $A$ program is an organized collection of activities designed to reach certain objectives." Program merupakan sebuah koleksi kegiatan yang dirancang untuk mencapai tujuan tertentu.
Evaluasi

program

dilaksanakan secara berkesinambungan seperti halnya yang dijelaskan oleh Joint Committee bahwa evaluasi program adalah evaluasi yang menafsir kegiatan pendidikan yang memberikan pelayanan pada suatu dasar kontinyu dan sering melibatkan tawaran-tawaran kurikulum. Pendapat ini diperjelas oleh Cronbach dan Stufflebeam yang mengemukakan bahwa evaluasi program adalah upaya menyediakan informasi untuk disampaikan kepada pengambil keputusan.

Discrepancy Evaluation Model. Kata discrepancy berasal dari Bahasa Inggris, yang bila diterjemahkan ke dalam Bahasa Indonesia memiliki makna "kesenjangan". Model yang dikembangkan oleh Malcolm Provus ini merupakan model yang menekankan pada pandangan adanya kesenjangan dalam pelaksanaan program. Evaluasi program yang dilkukan oleh evaluator mengukur besarnya kesenjangan yang ada pada setiap komponen. Kesenjangan yang dimaksud disini adalah perbedaan antara yang seharusnya dicapai dengan yang sudah riil dicapai.

Pengertian kinerja yang cukup komprehensif dikemukakan oleh Frank Hertle yang menegaskan bahwa kinerja adalah suatu proses untuk menciptakan pemahaman bersama apa yang harus dicapai dan bagaimana hal itu harus dicapai, serta bagaimana mengatur orang dengan cara yang dapat meningkatkan kemungkinan tercapainya tujuan tersebut.

analisis $\begin{gathered}\text { Pembiayaan adalah sebuah } \\ \text { terhadap sumber-sumber }\end{gathered}$ pendapatan (revenue) dan penggunaan biaya (expenditure) yang diperuntukkan sebagai pengelolaan pendidikan secara efektif dan efisien dalam rangka mencapai tujuan yang telah ditentukan. Sarana pendidikan adalah semua peralatan atau fasilitas yang langsung digunakan dalam proses belajar 
mengajar agar tujuan pendidikan dapat tercapai.

Prasarana pendidikan adalah alat yang tidak langsung yang digunakan untuk mencapai tujuan pendidikan.

Sarana dan Prasarana merupakan penunjang suksesnya proses pembelajaran di lembaga pendidikan. Sarana dan prasarana pendidikan menjadi hal yang menjadi perhatian bagi setiap lembaga pendidikan. Terkadang sarana dan prasarana menjadi tolak ukur kualitas suatu lembaga pendidikan.

Sistem informasi menjadi bagian penting dalam suatu organisasi, dengan adanya informasi system dapat membantu kinerja yang ada di organisasi dari mulai input, proses dan output. Dalam rentetan proses tersebut system informasi sangat dibutuhkan, system informasi dalam organisasi juga dibutuhkan dalam mengambil keputusan. Selain untuk mengambil keputusan system informasi juga dapat menjadi sumber-sumber informasi bagi siapa saja yang membutuhkan informasi untuk internal maupun eksternal organisasi.

Menurut Peraturan Menteri Pendidikan dan Kebudayaan No.49 Tahun 2014 pengabdian kepada masyarakat adalah kegiatan sivitas akademika yang memanfaatkan ilmu pengetahuan dan teknologi untuk memajukan kesejahteraan masyarakat dan mencerdaskan kehidupan bangsa. Bila diberi pengertian yang lebih luas Pengabdian kepada Masyarakat adalah kegiatan-kegiatan yang mencakup upaya-upaya peningkatan kualitas sumber daya manusia, baik dalam hal wawasan, pengetahuan maupun peningkatan keterampilan yang dilakukan oleh sivitas akademika sebagai perwujudan darma bakti serta wujud kepedulian untuk berperan aktif meningkatkan kesejahteraan dan memberdayakan masyarakat luas terlebih bagi masyarakat ekonomi lemah.
Kinerja merupakan proses perilaku yang berhubungan dengan tujuan organisasi yang dapat dilihat dari tingkat keberhasilan dan kualitas pencapaian tugas yang sesuai dengan standar acuan yang telah ditetapkan selama periode tertentu. Kinerja dapat dikatakan sebagai tolak ukur keberhasilan program studi. Dalam pelaksanaannya kinerja tidak dapat dilepaskan dari komponen yang berkaitan langsung dalam memberikan pengaruh terhadap capaian kerja suatu program studi. Komponen diantaranya adalah pembiayaan, sarana dan prasarana, sistem informasi, penelitian, pelayanan/Pengabdian masyarakat serta kerjasama. Komponen-komponen itulah yang dijadikan objek pengamatan di dalam penelitian evaluasi lembaga.

Evaluasi dilakukan untuk menjawab pertanyaan dan untuk menerapkan kriteria didalam menentukan nilai atau kebermaknaan sesuatu. Dalam hal ini, kriteria adalah ukuran ideal yang dijadikan tolak ukur keberhasilan penyelenggaraan Kinerja Program Studi Administrasi Pendidikan Fakultas Ilmu Pendidikan Universitas Negeri Jakarta. Kriteria disusun sebagai pedoman evaluator dalam melaksakan evaluasi program. Disusunnya kriteria, evaluator menjadi lebih mantap karena ada patokan, dapat digunakan sebagai bukti pertanggungjawaban dari hasil evaluasi, untuk menghindari subjektivitas evaluator, dan hasil evaluasi sama walaupun evaluator berbeda. Patokan yang ditetapkan berdasarkan kriteria Standar dan Prosedur Akreditasi Program Studi Sarjana pada jenjang Perguruan Tinggi. yang dibatasi pada pembiayaan, sarana dan prasarana, sistem informasi manajemen dan Penelitian, Pelayanan/pengabdian kepada masyarakat dan kerjasama. 


\section{Metodologi Penelitian}

Tujuan khusus yang ingin dicapai melalui penelitian ini yaitu mengetahui sejauh mana kinerja Program Studi Admistrasi Pendidikan Fakultas Ilmu Pendidikan Universitas Negeri Jakarta. Yang dapat dilihat melalui pembiayaan, sarana dan prasarana, system informasi, penelitian, pengabdian masyarakat.

Penelitian evaluatif dengan metode deskripstif ini dilakukan untuk melihat mengenai kinerja program studi Administrasi Pendidikan Fakultas Ilmu Pendidikan Universitas Negeri Jakarta dengan menggunakan pendekatan kuantitatif dan kualitatif. Model evaluasi yang digunakan yaitu model Discrepancy Evaluation Model (DEM) yaitu evalusi mengenai kesenjangan suatu program yang berdasarkan suatu keadaan antara yang diharapkan dalam rencana dengan yang dihasilkan dalam pelaksanaan program. Evaluasi kesenjangan dimaksudkan untuk mengetahui tingkat kesesuaian antara standar yang sudah ditentukan dalam program dengan penampilan aktual dari program tersebut.

Sumber data penelitian ini diambil dari beberapa narasumber melalui wawancara secara mendalam dengan menggunakan teknik purposive sampling (sampel bertujuan), pengambilan sampel dilakukan secara sengaja sesuai dengan persyaratan sampel yang diperlukan berdasarkan pada kebijaksanaan penelitian itu sendiri. Peneliti menentukan sendiri sampel yang diambil karena pertimbangan tertentu. Teknik ini dipilih karena narasumber dapat mewakili karakteristik dari populasi yang telah dikenal sebelumnya.

Pemilihan informan didasarkan pada pertimbangan tertentu berdasarkan pengaruh atau keterlibatan informan dalam kegiatan tercapainya kinerja program studi Administrasi Pendidikan
Fakultas Ilmu Pendidikan Universitas Negeri Jakarta sebagai contoh orang tersebut dianggap memiliki informasi mengenai sejauh mana kinerja yang telah dicapai sehingga memudahkan peneliti dalam memahami objek dan lingkungan tempat penelitian. Peneliti menetapkan informan sebagai berikut: 1) Koordinator Program Studi Administrasi Pendidikan Fakultas Ilmu Pendidikan sebagai key informan, 2) Staf Tata Usaha Program Studi Administrasi Pendidikan Fakultas Ilmu Pendidikan sebagai informan pendukung I, dan 3) Dosen Program Studi Administrasi Pendidikan Fakultas Ilmu Pendidikan sebagai informan pendukung II. Kemudian data dianggap telah cukup memadai ketika sudah tidak dibutuhkannya informan selanjutnya karena boleh dikatakan tidak diperoleh lagi tambahan informasi yang berarti.

Alat untuk pengumpulan data yang digunakan dalam penelitian evaluasi ini adalah: Observasi, Dokumentasi, dan Wawancara.

Adapun tahapan penelitian menggunakan model DEM yakni sebagai berikut:

1. Tahap Penyusunan Desain Dalam tahap ini dilakukan kegiatan merumuskan tujuan program, meyiapkan kelengkapan penelitian serta merumuskan standar dalam bentuk rumusan yang menunjuk pada suatu yang dapat diukur.

2. Tahap Penetapan Kelengkapan Program

Dalam tahap ini dilakukan kegiatan meninjau kembali penetapan standar, meninjau program yang sedang berjalan, meneliti kesenjangan antara yang direncanakan dengan yang sudah dicapai dengan sebelumnya memastikan ketersediaan kelengkapan penelitian.

3. Tahap Proses (Process)

Mengadakan evaluasi, tujuan tujuan manakah yang sudah dicapai. Tahap 


$$
\begin{aligned}
& \text { ini juga disebut tahap } \\
& \text { "mengumpulkan data dari } \\
& \text { pelaksanaan program" }
\end{aligned}
$$

4. Tahap Pengukuran Tujuan (Product)

Melakukan analisis data dan menetapkan tingkat output yang diperoleh dengan mengetahui apakah program sudah mencapai tujuan.

5. Tahap Pembandingan (Programe Comparison)

Tahap membandingkan hasil yang telah dicapai dengan tujuan yang telah ditetapkan dengan menuliskan semua penemuan kesenjangan.

Sebelumnya data hasil penelitian dianalisis secara deskriptif baik secara umum maupun secara khusus. Data penelitian dipaparkan dalam bentuk tabel dan tabulasi presentase. Dengan penghitungan sebagai berikut:

\section{NK=Bobot Komponen $\quad X \quad$ Skor Perolehan \\ NA $=\Sigma$ NK : Skor Tertinggi X 100\%}

Dalam tahap definisi, fokus kegiatan dilakukan untuk merumuskan tujuan, proses atau aktifitas, serta pengalokasian sumberdaya dan partisipan untuk melakukan aktifitas dan mencapai tujuan-tujuan yang telah ditetapkan. Selama tahap instalasi, rancangan program digunakan sebagai standar untuk mempertimbangkan langkah-langkah operasional program. Pada tahap proses, evaluasi difokuskan pada upaya bagaimana memperoleh data tentang kemajuan para peserta program, untuk menentukan apakah perilakunya berubah sesuai dengan yang diharapkan atau tidak. Selama tahap produk, penilaian dilakukan untuk menentukan apakah tujuan akhir program tercapai atau tidak.

Evaluasi kinerja program studi Administrasi Pendidikan Fakultas Ilmu Pendidikan Universitas Negeri Jakarta ini menggunakan dua jenis instrumen yaitu studi dokumen, dan pedoman wawancara. Studi dokumentasi dilakukan dengan mengumpulan dokumentasi yang berhubungan baik dengan lokasi penelitian, surat-surat mengenai pelaksanaan kegiatan kinerja dan dokumentasi lainnya yang berhubungan data yang dibutuhkan dalam penelitian maupun dalam pelaksanaan kinerja program studi Administrasi Pendidikan. Pedoman wawancara dibuat untuk memuat garisgaris besar yang akan ditanyakan kepada informan dalam mengungkap hal-hal yang berkaitan dengan data yang bermanfaat untuk dijadikan dasar penelitian.

\section{Hasil dan Pembahasan}

Penelitian ini menggunaan model evaluasi. Model evaluasi yang digunakan yaitu model Discrepancy Evaluation Model (DEM) yaitu evalusi mengenai kesenjangan suatu program yang berdasarkan suatu keadaan antara yang diharapkan dalam rencana dengan yang dihasilkan dalam pelaksanaan program. Evaluasi kesenjangan dimaksudkan untuk mengetahui tingkat kesesuaian antara standar yang sudah ditentukan dalam program dengan penampilan aktual dari program tersebut. Dengan menggunakan model DEM, maka kegiatan evaluasi kinerja program studi Administrasi Pendidikan Fakultas Ilmu Pendidikan Universitas Negeri Jakarta dapat dilakukan perbandingan antara standar yang telah ditetapkan dengan kenyataan di lapangan. Data-data yang diambil dalam penelitian ini dari rentang waktu tahun 2013-2015.

\section{Pembiayaan}

Administrasi Pendidikan
tidak ikut terlibat dalam
penyusunan pembiayaan akreditasi.
Sehingga untuk persiapan akreditasi
program studi dapat bekerja sama
dengan pihak fakultas. Kerjasama


dengan fakultas dalam memenuhi data-data maupun dokumen yang dibutuhkan. Tingkat pencapaian pada subfokus pembiayaan tidak dapat dihitung dikarena peraturan pemerintah yang telah mengatur bahwa Badan Layanan Umum harus mengikuti peraturan yang ada dan pihak fakultas dan universitas yang berwenang dalam subfokus pembiayaan ini.

\section{Sarana dan Prasarana}

Selain ruang kelas ada beberapa sarana yang dimiliki program studi untuk menunjang perkuliahan dan kegiatan mahasiswa. Fasilitas tersebut diantara lain, Lab komputer, perpustakaan, tempat olah raga, poliklinik, ruang Himpunan Mahasiswa, Audotorium, ruang kelas yang dilengkapi dengan perlengkapan yang memadahi, dan ruang dosen.

Penilaian sarana dan prasaran berdasarkan pedoman akreditasi didasarkan beberapa aspek diantaranya dari ruang kerja dosen,prasarana yang menunjang proses pembelajaran. Akses dan pendayagunaan sarana yang dipergunakan dalam proses administrasi dan pembelajaran serta penyeleng-garaan kegiatan Tridharma PT secara efektif.

Sehingga jika dilihat dari pedoman matriks penilaian akreditasi sarjana tingkat pencapaian yang didapat oleh Prodi Administrasi Pendidikan mendapat nilai . Maka untuk menghitung tingkat pencapaian, sebagai berikut

Tingkat Pencapaian = $\frac{\text { Jumlah skoryang diperoleh }}{\text { jumlah skormaksimal }} \times$ $100 \%$

$=\frac{3}{4} \times 100 \%=75 \%$

Tingkat Pencapaian sarana dan prasarana secara keseluruhan
Tingkat Pencapaian = Jumlah skor (96) yang diperoleh

jumlah konten

$$
=\frac{750 \%}{10}=75 \%
$$

Tingkat pencapaian sarana dan prasaran mencapai $75 \%$ hal ini dikarena masih ada beberapa saran dan prasarana yang masih belum terpenuhi sesuai dengan standar. Program studi masih harus memenuhi kelengkapan saran dan prasarana sebagai penunjang kegiatan akademik. Perpustakaan dan kelengkapan bahan pustaka menjadi focus yang harus dilengkapi dan dipenuhi .

\section{Sistem Informasi}

Sistem Informasi yang ada di Prgram Studi Administrasi Pendidikan sudah baik dan terus dalam pengumpayaan terhadap sistem yang lebih baik. Sistem Informasi dibagi dua point penilaian yang pertama yaitu Akses dan pendayagunaan sistem informasi dalam pengelolaan data dan informasi tentang penyelenggaraan program akademik di program studi (hardware, software, e-learning, perpustakaan, dll.). Point pertama ini mendapat nilai 3 karena di program studi Administrasi Pendidikan sistem informasi dengan komputer yang terhubung dengan jaringan luas/internet, software yang berlisensi dengan jumlah yang memadai. Tersedia fasilitas e-learning namun belum dimanfaatkan secara efektif. Koleksi perpustakaan dapat diakses secara on-line namun masih ada kendala dalam kecepatan akses. Sedangkan point ke dua dengan penilaian Akses dan pendayagunaan sistem informasi mendapat poin 3 . Hal ini karena masih ada penggunaan sistem manual dalam kegiatan program 
studi. Sehingga jika dilihat dari pedoman matriks penilaian akreditasi sarjana tingkat pencapaian yang didapat oleh Prodi Administrasi Pendidikan mendapat nilai $75 \%$. Maka untuk menghitung tingkat pencapaian, sebagai berikut: TingkatPencapaian

$\frac{\text { Jumlah skoryang diperoleh }}{\text { jumlah skormaksimal }} \times$ $100 \%$

$=\frac{3}{4} \times 100 \%$

$=75 \%$

Evaluasi program yang dilakukan oleh evaluator mengukur besarnya kesenjangan yang ada pada setiap komponen. Kesenjangan yang dimaksud disini adalah perbedaan antara yang seharusnya dicapai dengan yang sudah riil dicapai. Berdasarkan perhitungan dan pengamatan lapangan sistem informasi harus masih dilakukan pengoptimalisasian dan perbaikan. Evaluasi yang peneliti dapat sarankan adalah Pengoptimalisasian website yang dimiliki program studi merupakan hal yang menjadi perhatian. Memperjelas isi dari website dan selalu update. Sosialisasi terhadap publikasi sistem informasi yang dipunya semisal website maupun perpustakaan online yang miliki oleh fakultas. Memaksimalkan program aplikasi (OpenMK) yang dimiliki program studi untuk menyimpan dokumen dan persiapan akreditasi. Memaksimalkan laboraturium Administrasi Pendidikan untuk memaksimalkan sistem informasi dan pembelajaran bagi Mahasiswa untuk lebih terkini dalam dunia teknologi.

4. Penelitian, Pengabdian Masyarakat dan Kerjasama

a. Penelitian
Selama tiga tahun ini program studi Administrasi Pendidikan ada 19 penelitian dosen.Jumlah penelitian yang sesuai dengan bidang keilmuan PS, yang dilakukan oleh dosen tetap yang bidang keahliannya sama dengan PS, selama 3 tahun.Penilaian dilakukan dengan penghitungan berikut:

NK $=\quad$ Nilai

$\operatorname{kasar}=\frac{4 \times n_{a}+2 \times n_{b}+n_{c}}{f}$

Keterangan:

$\mathrm{n}_{\mathrm{a}}=$ Jumlah penelitian dengan biaya luar negeri yang sesuai bidang ilmu

$\mathrm{n}_{\mathrm{b}}=$ Jumlah penelitian dengan biaya luar yang sesuai bidang ilmu

$\mathrm{n}_{\mathrm{c}}=$ Jumlah penelitian dengan biaya dari PT/sendiri yang sesuai bidang ilmu

$\mathrm{f}=$ Jumlah dosen tetap yang bidang keahliannya sesuai dengan PS

Setelah dilakukan penelusuran berkas yang ada di Program Studi Administrasi Pendidikan, maka perhitungan penelitian sebagai berikut:

NK $=$ Nilai kasar $=\frac{19}{21}=0,9048$

Nilai kasar yang diperoleh adalah 0,9048 .

Jika $0<\mathrm{NK}<2$, maka skor $=$ $(1.5 \times \mathrm{NK})+1$

Skor $=(1,5 \times 0,9048)+1=1,35$ $+1=2,4=\mathbf{2}$

Skor 2 yang diperoleh menandakan bahwa penelitian yang ada di prgram studi cukup. Penelitian yang ada di program studi Administrasi Pendidikan harus ditingkatkan lagi dengan mewajibkan dosen-dosen untuk terlibat aktif dan membuat penelitian yang relevan dengan program studi. 


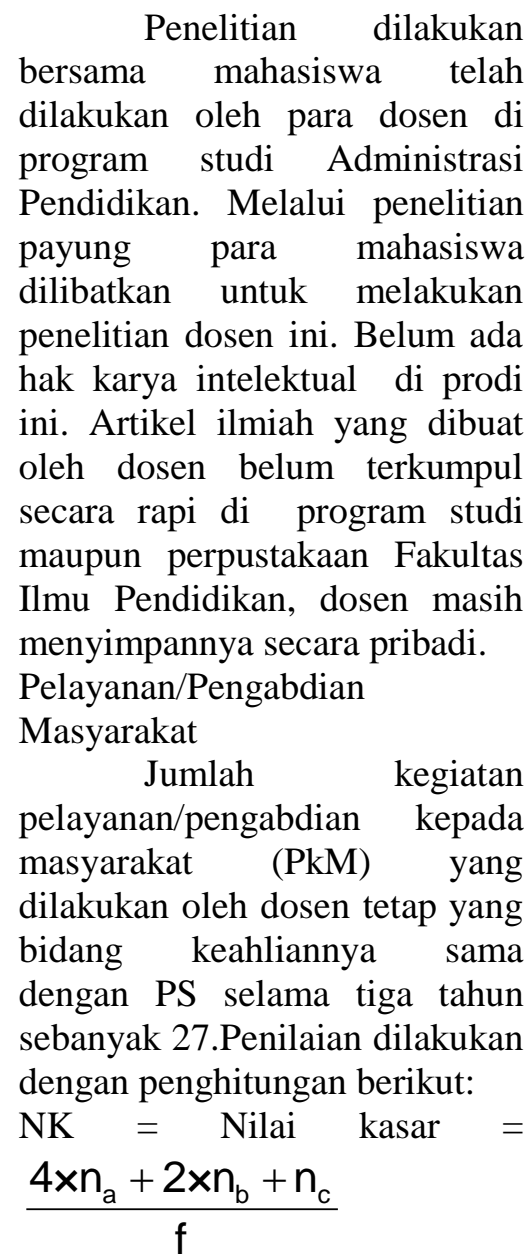

Keterangan:

$\mathrm{n}_{\mathrm{a}}=$ Jumlah kegiatan PkM dengan biaya luar negeri yang sesuai bidang ilmu

$\mathrm{n}_{\mathrm{b}}=$ Jumlah kegiatan PkM dengan biaya luar yang sesuai bidang ilmu

$\mathrm{n}_{\mathrm{c}}=$ Jumlah kegiatan PkM dengan biaya dari PT/sendiri yang sesuai bidang ilmu

$\mathrm{f}=$ Jumlah dosen tetap yang bidang keahliannya sesuai dengan PS

Setelah dilakukan penelusuran berkas yang ada di Program Studi Administrasi Pendidikan, maka perhitungan pengabdian masyarakat sebagai berikut:

$\mathrm{NK}=$ Nilai $\mathrm{kasar}=\frac{27}{21}=1,286$
Nilai kasar yang diperoleh adalah 1,286.

Jika NK $\geq 1$, maka skor $=4$.

Pengabdian masyarakat yang dilakukan oleh dosendosen prodi Administrasi Pendidikan melibatkan Mahasiswa. Keterlibatan Mahasiswa dalam hal ini dapat menjadi nilai tambah dan berpengaruh atas penilaian PS. Pengabdian masyarakat yang melibatkan mahasiswa, dosen menjadi penanggungjawab dari keberlangsungan pengabdian.

Pengabdian masyarakat juga dilakukan oleh mahasiswamahasiswa prodi Administrasi Pendidikan melalui Himpunan Mahasiswa Administrasi Pendidikan. Pengabdian ini dilakukan mahasiswa di daerahdaerah terpencil dan disana mereka mengabdi untuk memberikan pengalaman dan ilmu-ilmu mereka. Dalam hal ini mahasiswa diberikan kepercayaan dan tanggung jawab untuk melaksanakan program pengabdian masyarakat.

Pengabdian masyarakat sudah dilaksanakan dengan baik dengan melibatkan dosen serta mahasiswa. Tri dharma perguruan tinggi bukan hanya menjadi semboyan semata tetapi mampu direalisasikan dengan baik. Namun catatan untuk pengabdian masyarakat di Program Studi Administrasi Pendidikan harus mampu ditingkatkan kembali pengabdian yang dilaksanakan.

c. Kerjasama 
Kerjasama yang dilakukan oleh Program Studi Administrasi Pendidikan belum banyak. Kebijakan untuk kerjasama diakukan oleh jajaran tingkat fakultas, sehingga kerjasama yang dilakukan tataran tingkat prodi tidak begitu banyak. Kerjasama yang sering dilakukan setiap tahunnya adalah kerjsama dengan Sekolah Dasar yang ada di daerah Jakarta serta Dinas Pendidikan Jakarta untuk kegiatan magang. Program studi bekerjasama dengan para alumni untuk berbagi pengalaman terkait dunia kerja. Forum alumni yang telah terbentuk ini dapat dimanfaatkan untuk menjalin silahturahmi serta berbagi info mengenai pengalaman kerja maupun lowongan pekerjaan.

Penelitian, pengabdian kepada masyarakat serta kerja sama yang dilakukan oleh prodi Administrasi Pendidikan dapat dihitung berdasarkan pedoman akeditasi . tingkat pencapaian, sebagai berikut:

Tingkat Pencapaian $=$

$\frac{\text { Jumlah skoryang diperoleh }}{\text { jumlah skormaksimal }} \times$

$100 \%$

$=\frac{4}{4} \times 100 \%$

$=100 \%$

Tingkat Pencapaian secara keseluruhan

Tingkat Pencapaian $=$ Jumlah skor (96) yang diperoleh

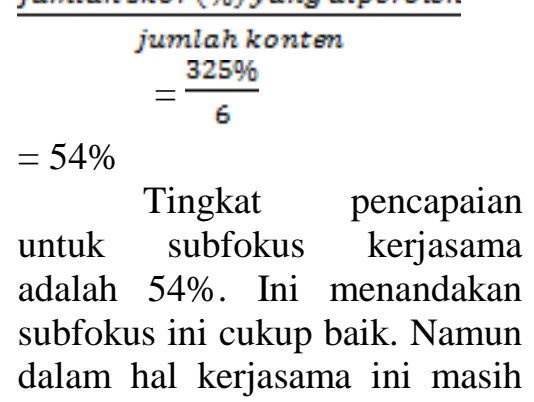

berhubungan dengan pihak fakultas. Semua atas persetujuan fakultas. Kerjasama juga dipusatkan di tataran tingkat fakultas.

Kesenjangan yang ada di penelitian dapat dilakukan dengan pengumpulan artikel ilmiah secara berkala di prodi. Peningkatan penelitian dapat dilakukan dengan mengajak mahasiswa dalam penelitian dosen. .Peningkatan pengabdian kepada masyarakat dapat dilakukan dengan mahasiswa guna merealisasikannya..

Peningkatan subfokus penelitian dan pengabdian kepada masyarakat ini dapat melibatkan mahasiswa untuk merealisasikannya. Perapihan dokumentasi hasil penelitian serta kerjasama harus terus ditingkatkan sehingga pelaksanaan akreditasi nantinya dapat disiapkan dengan baik.

\section{Kesimpulan dan Implikasi}

a. Kesimpulan

Pertama, komponen kinerja pada aspek pembiayaan, meliputi: 1) Keterlibatan program studi dalam perencanaan target kinerja, perencanaan kegiatan/ kerja dan perencanaan alokasi dan pengelolaan dana, dan 2) Dana operasional dan pengembangan (termasuk hibah) dalam mendukung kegiatan program akademik (pendidikan, penelitian, dan pengabdian kepada masyarakat) program studi harus memenuhi syarat kelayakan jumlah dan tepat waktu. Peneliti tidak mengevaluasi komponen pembiayaan. Hal ini karena aspek pembiayaan tidak dikelola langsung oleh program studi. Pengelolaan biaya dilaksanakan oleh pihak fakultas dan universitas, program studi 
hanya ada ditataran sebagai pelaksana saja.

Kedua, komponen yang ada dari sarana dan prasarana, meliputi: 1) Ruang kerja dosen yang memenuhi kelayakan dan mutu untuk melakukan aktivitas kerja, pengembangan diri, dan pelayanan akademik, dan 2) Akses dan pendayagunaan sarana yang dipergunakan dalam proses administrasi dan pembelajaran serta penyelenggaraan kegiatan Tridharma PT secara efektif. Dari dua aspek tersebut menunjukan presentase dalam katagori baik. program studi Administrasi Pendidikan memiliki Luas ruang kerja dosen yang memadahi. Terdapat prasarana yang menunjang proses pembelajaran diantara lain adanya Laboratorium, ruang himpunan mahasiswa, tempat olahraga, perpustakaan, poliklinik dll. Perpustakaan yang berada di fakultas perlu adanya penambahan buku dan bahan pustaka lainnya guna menambah referensi dosen maupun mahasiswa. Program studi memiliki laboraturium yang kondisinya cukup baik dan dapat digunakan oleh Mahasiswa untuk belajar maupun mengerjakan tugas.

Ketiga, kompenen system informasi memiliki aspek, meliputi: 1) Akses dan pendayagunaan sistem informasi dalam pengelolaan data dan informasi tentang penyelenggaraan program akademik di program studi, dan 2) Akses dan pendayagunaan sistem informasi. Dari dua aspek tersebut menunjukan presentase dalam katagori baik. System informasi sudah mulai dikembangkan dengan memanfaatkan website prodi yang dibuat yaitu www.mpfipunj.org. Sistem informasi bidang akademik melalui siakad yang dapat diakses oleh civitas akademika. Program studi secara berlahan memanfaakan teknologi yang ada untuk memberikan informasi kepada civitas akademika maupun masyarakat luas.

Keempat, kompenen penelitian, pengabdian masyarakat dan kerjasama memiliki aspek yang meliputi: 1) Produktivitas dan mutu hasil penelitian dosen dalam kegiatan penelitian, pelayanan/pengabdian kepada masyarakat, dan kerjasama, dan keterlibatan mahasiswa dalam kegiatan tersebut, 2) Kegiatan pelayanan/pengabdian kepada masyarakat dosen dan mahasiswa program studi yang bermanfaat bagi pemangku kepentingan (kerjasama, karya, penelitian, dan pemanfaatan jasa/produk kepakaran), 3) Jumlah dan mutu Jumlah dan mutu kerjasama yang efektif yang mendukung pelaksanaan misi program studi dan institusi dan dampak kerjasama untuk penyelenggaraan dan pengembangan program studi. Dari tiga aspek tersebut menunjukan presentase dalam katagori cukup baik. Penelitian dan pengabdian kepada masyarakat yang dilakukan oleh dosen juga melibatkan mahasiswa. Belum adanya karya program studi yang memperoleh HaKi. Kerjasama belum banyak yang dilakukan oleh Program Studi Adiministrasi Pendidikan. Kerjasama yang dilakukan dinaungi oleh fakultas.

Berdasarkan perolehan keempat komponen di atas, maka dapat dikata kinerja Administrasi Pendidikan Fakultas Ilmu Pendidikan UNJ dari aspek pembiayaan, sarana dan prasarana, sistem informasi, penelitian, pengabdian dan kerjasama menunjukkan kategori baik.

b. Implikasi 
Evaluasi adalah alat untuk mengukur sejauh mana kinerja yang telah dicapai. Kinerja program studi dapat dilihat melalui syarat yang telah ditentukan. Pembiayaan, Sarana dan Prasarana, Sistem Informasi, penelitian, pengabdian kepada masyarakat dan kerjasama merupakan komponen yang menjadi syarat meningkatnya kinerja program studi. Peningkatan kinerja mampu dilakukan dengan melihat evaluasi yang telah dilakukan. Evaluasi ini berdampak kepada peningkatan kinerja program studi. Hal ini salah satu untuk mempersiapkan akreditasi. Hal tersebut diusahakan agar dipenuhi dengan baik oleh Program Studi .

Dilakukannya penelitian
dengan metode evaluasi ini
berimplikasi kepada persiapan
akreditasi. Sehingga program studi
mampu mengetahui apa saja yang
dirasa perlu dilengkapi dan
perapihan data yang dibutuhkan
sebelum akreditasi dilaksanakan.

\section{Saran}

Berdasarkan penelitian yang telah dilakukan, peneliti mengajukan beberapa saran:

1. Fakultas Ilmu Pendidikan, Kerjasama kepada program studi yang ada di Fakultas Ilmu Pendidikan untuk meningkatkan kualitas pendidikan yang ada. Pengadaan dan pemeliharaan sarana dan prasarana yang ada harus diperhatikan agar tercipta suasana belajar yang baik. Melengkapi lebih banyak lagi bahan pustaka yang ada di perpustakaan Fakultas Ilmu Pendidikan.

2. Bagi Program Studi, Perapihan dokumen dan administrasi yang berhubungan dengan program studi harus lebih ditindaklanjuti secara rapih dan professional. Persiapan terhadap akreditasi sudah mulai persiapkan secara berlahan. Sehingga tidak terjadi kekurangan yang akan mempersulit ketika akreditasi. Sehingga akreditasi yang sangat baik itu dapat dipertahankan. Kerjasama dengan para alumni untuk menjalin kerjasama.

3. Dosen-Dosen Administrasi Pendidikan. Melibatkan mahasiswa dalam penelitian maupun pengabdian kepada masyarakat. Segala bentuk prestasi yang dimiliki oleh dosen alangkah baiknya dikumpulkan di kantor program studi. Sebagai contoh adalah artikel ilmiah/buku/penelitian yang pernah dilakukan.

4. Civitas akademika administrasi pendidikan. Saling membantu untuk merawat segala yang sudah diberikan fasilitasnya, misal: sarana dan prasarana dll.

\section{Daftar Pustaka}

Armstrong, Michel. 2009. Armstrong's Handbook of Manajemen and Leadership. London: Kogan Page.

Arum, Wahyu Sri Ambar. 2007. Manajemen Sarana dan Prasarana Pendidikan. Jakarta: Multi Karya Utama.

Ellitan, Lena. Lina Anatan. 2007. Sistem Informasi Manajemen Konsep dan Praktis. Bandung: Alfabet.

Gibson James L. et al. 2005. Organization Behavior, Structure, Processes. New York:McGraw-Hill Irwin.

Mahapatro, B.B. 2010. Human Resource Management.New Delhi: New Age International Limited Publishers.

Mangkuprawira, Sjafri/Sjahri. 2004. Manajemen Sumber Daya 
Manusia Strategik. Jakarta: Ghalia Indonesia.

Moleong, Lexy J. 2005. Metodologi Penelitian Kualitatif. Bandung: Remaja Rosdakarya

Mullins, Laurie J. 2009. Management and Organisational Behaviour. England: Prentice Hall.

Mulyono. 2010. Konsep Pembiayaan Pendidikan. Jogjakarta: Ar-Ruzz Media.

Murni, Trisna. Sri Warsono. 2013. Analisis Penilaian Kinerja Dosen Fakultas Ekonomi dan Bisnis Universitas Bengkulu, 2013. Bengkulu: Universitas Bengkulu.

Sedarmayanti. 2007. Manajemen Sumber Daya Manusia. Bandung: PT. Refika Aditama.

Simamora, Henry. 2004 Manajemen Sumber Daya Manusia. Yogyakarta: STIEKE YKPN.

Sneel, Bohlaner. 2013. Managing Human Resources. USA: SouthWestern Cengage Learning.
Subekti, Akhmad. Mohammad Jauhar. 2012. Pengantar Manajemen Sumber Daya Manusia. Jakarta: Prestasi Pustaka.

Sugiyono.2014. Memahami Penelitian Kualitatif. Bandung: CV. Alfabeta

Suryana, Asep. Tahap-Tahapan Penelitian Kualitatif Mata Kuliah Analisis Data Kualitatif (http://file.upi.edu/Direktori/FIP /JUR. ADMINISTRASI PEND IDIKAN/197203211999031ASEP_SURYANA/Copy_(4)_o f_LANGKAH_PENELITIAN_ KUALITATIF.pdf) diakses pada tanggal 24 Maret 2016 pukul 22.33 WIB

Trauna, Dody S. Rudi Ahmad Suryadi. 2013. Paradigma Pendidikan Berkualitas. Bandung: Pustaka Setia.

Uno, Hamzah B. 2012. Teori Kinerja dan Pengukurannya, Jakarta: Bumi 